\title{
Liver Transplantation in Man-III, Studies of Liver Function, Histology, and Immunosuppressive Therapy
}

ROGER WILLIAMS, ${ }^{1}$ M.D., F.R.C.P. ; R. Y. CALNE, ${ }^{2}$ M.A., M.S., F.R.C.S. ; I. D. ANSELL, ${ }^{3}$ M.B., B.CHIR. B. S. ASHBY, ${ }^{4}$ M.B., F.R.C.S. ; P. A. CULLUM, ${ }^{5}$ M.B., F.R.C.S. ; J. L. DAWSON, ${ }^{6}$ M.S., F.R.C.S.

A. L. W. F. EDDLESTON, ${ }^{7}$ B.M., M.R.C.P. ; D. B. EVANS, ${ }^{8}$ M.B., M.R.C.P. ; P. T. FLUTE, ${ }^{9}$ M.D., M.C.PATH. P. M. HERBERTSON, ${ }^{10}$ M.A., M.D., M.C.PATH. ; V: JOYSEY, ${ }^{11}$ B.SC., PH.D. ; A. M. C. MCGREGOR, ${ }^{4}$ M.B., F.R.C.S. P. R. MILLARD, ${ }^{12}$ M.B., B.S. ; I. M. MURRAY-LYON, ${ }^{13}$ M.B., M.R.C.P., M.R.C.P.ED.

J. R. PENA, ${ }^{15}$ M.D. ; M. O. RAKE, ${ }^{14}$ M.B., B.SC., M.R.C.P. ; R. A. SELLS, ${ }^{15}$ M.A., F.R.C.S.

British Medical fournal, 1969, 3, 12-19

\begin{abstract}
Summary: The experience gained from 13 hepatic transplant operations is described, with particular reference to the findings in nine patients who survived the immediate operative period. A major problem was found to be infection. Fulminant pneumonia caused death in two adults, at a time when liver function was virtually normal. Infection related to bile fistula and sepsis may be overcome by an improved method of biliary drainage by cholecyst-dochostomy, which was carried out in the last two patients. Jaundice in the second week due to rejection was observed in several patients. The striking histological change was centrilobular cholestasis. The jaundice, which was not prevented by administration of antilymphocyte globulin, was rapidly controlled by temporarily increasing the dose of prednisone. One patient who survived for four and a half months and who had a poor tissue match subsequently developed chronic rejection with progressive cholestatic jaundice. Five of the patients were able to go home and at time of publication two are alive and well 14 and 20 weeks after treatment.
\end{abstract}

\section{Introduction}

In previous papers we described the organization of clinical liver transplantation in man and the collaborative programme being undertaken by a joint team from Addenbrooke's Hospital, Cambridge, and King's College Hospital, London (Calne and Williams, 1968 ; Calne et al., 1968). Operative details of the first five cases were reported, together with the long survival of two of the patients-one who had lived for 11 weeks and another who had returned to work at the time of that report. Subsequent experience of eight further transplant operations has led us to modify our approach to certain aspects of the surgery, particularly bile drainage, and to the immunosuppressive therapy needed for these patients. In this paper we describe the overall results, with particular emphasis on the clinical course, changes in liver function, and histology of the nine patients who have survived the immediate postoperative period.

${ }^{1}$ Director, Medical Research Council Group on Metabolism and Haemodynamics of Liver Disease, King's College Hospital, London S.E.5.

${ }^{2}$ Professor of Surgery, Addenbrooke's Hospital, Cambridge.

${ }^{3}$ Lecturer in Morbid Anatomy, King's College Hospital, London S.E.5.
Honorary Senior Surgical Registrar, Addenbrooke's Hospital, Cambridge.

Senior Lecturer in Surgery, King's College Hospital, London S.E.5.

Consultant Surgeon, King's College Hospital, London S.E.5.

Research Fellow, Medical Research Council on Metabolism and Haemodynamics of Liver Disease, King's College Hospital, London S.E.5.

${ }^{8}$ Consultant Physician, Addenbrooke's Hospital, Cambridge.

- Reader in Haematology, King's College Hospital Medical School, London S.E.5.

${ }^{10}$ Lecturer in Pathology, Addenbrooke's Hospital, Cambridge.

${ }^{11}$ Research Fellow, Department of Pathology, Addenbrooke's Hospital, Cambridge.

${ }^{12}$ Demonstrator in Pathology, Addenbrooke's Hospital, Cambridge.

${ }^{4}$ Medical Registrar, King's College Hospital, London S.E.5.

${ }^{25}$ Senior Surgical Registrar, Addenbrooke's Hospital, Cambridge.

\section{Complete Series}

The 13 patients who have been treated by hepatic transplantation, including two children with biliary atresia, the remainder comprising adult patients with carcinoma of the hepatic duct (2), primary hepatoma (4), and cirrhosis (5). In one of the children with biliary atresia and in one of the cirrhotic patients heterotopic transplantation was performed, the liver being placed as an auxiliary graft in the left hypochondrium after removal of the spleen. In the other cases orthotopic transplantation was carried out, the donor liver being inserted into the normal site after preliminary hepatectomy. Essentially the same operative technique, both for orthotopic and heterotopic transplantation, has been performed as in the initial cases reported (Calne and Williams, 1968) except that the preferred method of biliary drainage is now a cholecyst-dochostomy with preservation of the sphincter of Oddi.

Four patients died within 36 hours of the operation. In Case 1 the donor liver had been unperfused for an hour before transplantation, which caused irreversible ischaemic damage, and the recipient, a man with cirrhosis, died of uncontrollable haemorrhage. Case 2, a 10-month-old child with biliary atresia, regained consciousness at the end of operation but died of an unexplained cardiac arrest 30 minutes later. One of the more recent patients (Case 6), who had a hepatoma complicating cirrhosis with severe portal hypertension, died of uncontrollable haemorrhage. Case 13, a man of 37 with a primary hepatoma weighing $7 \mathrm{~kg}$. in whom an added complication was an unexpected stenosis of the donor coeliac artery, died 36 hours after operation from hypotension and peritonitis. The remaining nine patients survived the immediate postoperative period, and these cases are described below.

\section{Clinical Course and Survival}

\section{Biliary Atresia}

The second child with biliary atresia (Case 11) was aged 2 years 10 months. He was known from a previous laparotomy to have complete atresia of the biliary passages and gall bladder. Recently he had developed portal hypertension with bleeding from oesophageal varices.

Heterotopic transplantation was performed on 23 February 1969. The liver was placed in the splenic bed after preliminary splenectomy and the vascular anatomy reconstructed, as shown in Fig. 1. Biliary drainage was achieved by a cholecystjejunostomy. A liver biopsy at the end of the operation showed considerable necrosis of liver cells. Most of the sinusoids were engorged with blood with haemorrhage into the liver cell columns.

Postoperatively he was started on prednisone $(30 \mathrm{mg}$. daily) and azathioprine (18 mg. daily), but was extremely ill with 
paralytic ileus and renal failure. The blood urea rose to $220 \mathrm{mg}$. $/ 100 \mathrm{ml}$. during the first week and then fell to normal. The serum bilirubin, which was $16.5 \mathrm{mg} . / 100 \mathrm{ml}$. preopera-

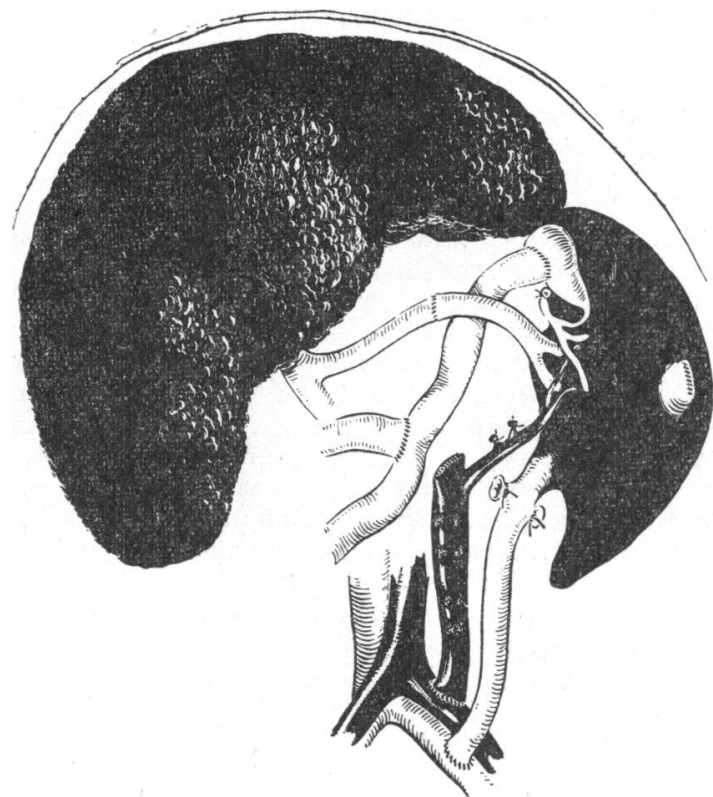

FIG. 1.-Case 11. Diagram of operative procedure showing the vascular connexions of the heterotopic liver allograft in the splenic bed.

tively, rose to a maximum of $28.6 \mathrm{mg}$. $/ 100 \mathrm{ml}$. on the fourth postoperative day. During the second week his condition improved and he passed bile pigments in the stools for the first time since birth. A liver scan showed good uptake of the technetium colloid in the allograft (Fig. 2). The serum bilirubin on 12 March had dropped to $12.9 \mathrm{mg}$. $/ 100 \mathrm{ml}$., but he then developed pneumonia and died on 14 March, 19 days after operation. At necropsy the vascular anastomoses were satisfactory. The auxiliary liver on histological examination showed centrilobular cholestasis and hepatocellular necrosis similar to that described for the orthotopic transplants. There was no portal tract infiltration.

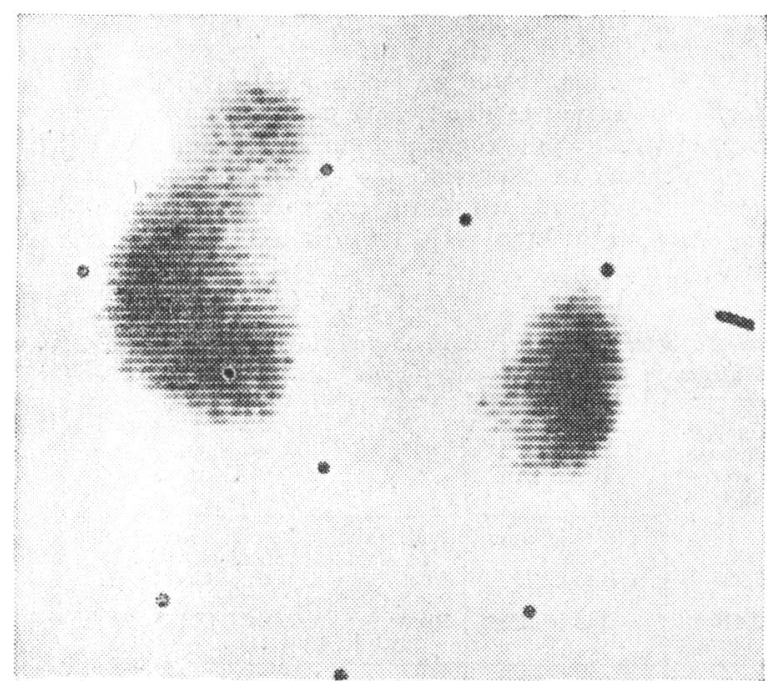

Fig. 2.-Case 11. Scintiscan on third day after transplantation, showing uptake of colloid both by heterotopic allograft and by the diseased liver. The dots indicate surface markings of costal margins, umbilicus, symphysis pubis, and iliac crests.

\section{Carcinoma of Hepatic Duct}

Both patients had had previous laparotomies and both were deeply jaundiced, with gross hepatic enlargement (Tables I and II).
Case 3 had also been treated with prednisone and chlorambucil, the latter resulting in marrow depression, septicaemia, and florid thrush. Full details of her course following orthotopic transplantation were given previously (Calne and Williams, 1968). She did well initially and went home on the 36th day. From the 10th day onwards she had a biliary fistula, and during the 11th week she developed a high fever and jaundice. A laparotomy showed necrosis of the gall bladder and she died a few days later. At necropsy the main finding was thrombosis of the recipient portion of the hepatic artery with widespread infarction of the liver.

Case 5 had had a polyethylene tube inserted through the growth at the previous laparotomy, and during removal of the liver a pocket of pus in the porta hepatis was opened. Biliary drainage was effected by anastomosis of the gall bladder to the jejunum with a Roux-en-Y loop. His postoperative course was never satisfactory. He had recurrent melaena, persistent intraperitoneal infection with Gram-negative organisms, and from the second week onwards obstructive jaundice. Laparotomy on the 17th day showed necrosis of the gall bladder, and though a satisfactory anastomosis was then achieved he died on the 22nd day from peritonitis.

\section{Primary Hepatoma}

All three patients presented with abdominal swelling and right upper quadrant pain and weight loss. In each case the diagnosis of a primary hepatoma involving both lobes but confined to the liver had been established at an earlier laparotomy.

One preoperative finding of considerable interest in Case 9 was a fasting serum calcium of $17.6 \mathrm{mg} . / 100 \mathrm{ml}$. and a serum inorganic phosphate of $1.4 \mathrm{mg} . / 100 \mathrm{ml}$. A full skeletal radiographic survey and bone scan provided no evidence of secondary deposits. Dr. R. W. Buckle demonstrated, by an immunoassay technique, a raised parathyroid hormone level in the blood of $0.47 \mathrm{~m} \mu \mathrm{g} . / \mathrm{ml}$. (normal up to $0.3 \mathrm{~m} \mu \mathrm{g}$. $/ \mathrm{ml}$.). No evidence of primary hyperparathyroidism was found, and it was concluded that the parathyroid hormone was being secreted by the tumour, this subsequently being confirmed by extraction of the tumour tissue after removal.

In each instance the recipient hepatectomy was difficult owing to the large size and vascularity of the neoplastic liver. Insertion of the donor liver was easier than in the other clinical groups, since there was ample space in the upper abdomen. In Cases 4 and 9 biliary drainage was by a choledocho-dochostomy, in Case 10 by a cholecyst-dochostomy. The immediate postoperative course was uncomplicated except in Case 4, who had to be reoperated on on the first day because of bleeding from the drainage wound.

The subsequent course of these patients is summarized in Table I. Case 4 returned to work in the sixth week but subsequently developed progressive jaundice, which required readmission in the third month. After intensive immunosuppression, which was complicated by a period of profound leucopenia, he developed signs of a midbrain lesion and died 19 weeks after transplantation. Necropsy showed fungal meningitis and diffuse bronchopneumonia with scattered firm nodules, up to $1 \mathrm{~cm}$. in diameter, from which pus containing Escherichia coli, Candida albicans, and cytomegalovirus was cultured.

In Case 9, the patient with hypercalcaemia, the serum calcium dropped to $10.2 \mathrm{mg} . / 100 \mathrm{ml}$. on the second postoperative day, thereafter fluctuating between 7 and $9.5 \mathrm{mg} . / 100 \mathrm{ml}$. with a serum phosphate of $2 \cdot 3-3 \mathrm{mg} . / 100 \mathrm{ml}$. The blood parathyroid hormone level was normal within 20 minutes of the hepatectomy. Unfortunately a biliary fistula delayed his discharge from hospital. He then did well at home, with stools of normal, colour and no jaundice, until he developed pneumonia. His condition rapidly deteriorated after readmission to hospital and he died 36 hours later, in the 10th week after transplantation. 
Necropsy showed a diffuse bronchopneumonia, the predominant organism being Aspergillus fumigatus.

Case 10 had transplantation with a cholecyst-dochostomy performed on 6 February 1969. She had no trouble with biliary drainage. She continues to do well at home doing housework and looking after her children, in the fifth month after transplantation.

\section{Cirrhosis}

All three patients were in an advanced stage of this disease (Table I).

\section{Case 8}

A 17-year-old boy with subacute hepatic necrosis was transferred to King's College Hospital on 12 December 1968, On examination he was in deep coma with no response to painful stimuli. The pupils were dilated and non-reactive. $\mathrm{He}$ was deeply jaundiced and the liver was not palpable. Investigation showed a severe thrombocytopenia with deficiency of most clotting factors.

After replacement therapy with fresh frozen plasma and fibrinogen, which produced little improvement in the in-vitro tests, transplantation was carried out. Considerable oedema of the peritoneal attachments of the liver and numerous dilated collateral blood vessels made the operation very difficult. Further fresh frozen plasma and fibrinogen were given during the operation, and fibrinolysis was also inhibited (Flute et al., 1969). A choledochodochostomy was performed and bile was dripping from the T-tube at the end of the operation. The cut surface of the removed liver (weight $1,110 \mathrm{~g}$.) showed dense stroma, in which were set nodules measuring up to $2 \mathrm{~cm}$. in diameter. Histological examination showed the architecture of the nodules to be completely disorganized and the centres necrotic. The intervening fibrous tissue contained numerous bile ducts and isolated hepatocytes, the overall appearances being consistent with subacute hepatic necrosis and early cirrhosis.

It was decided not to give immunosuppressive therapy because of the possible danger of reactivating the presumed viral hepatitis infection. He was conscious on the first postoperative day and talking on the second day. The E.E.G. showed striking improvement, with a maximum activity of 5 cycles/second compared with less than 2 cycles/second before operation. On the fifth day his temperature rose and he became confused. The following day he deteriorated further and the clotting factors showed an abnormal pattern for the first time since the transplant; he died suddenly later that day.

\section{Case 7}

A 57-year-old district nurse was diagnosed as having primary biliary cirrhosis in 1962. By 1968 her condition had deteriorated, with loss of weight, severe backache due to osteoporosis, together with increasing jaundice and ascites. She was confined to the home.
Transplantation was carried out in King's College Hospital on 3 November 1968 . Removal of the grossly cirrhotic liver proceeded uneventfully and only 8 pints ( 4.5 litres) of blood was transfused, with a total operating time of five hours. The removed liver was grossly nodular, and histological examination showed late-stage primary biliary cirrhosis with marked periportal cholestasis, piecemeal necrosis, and infrequent bile ducts.

The immediate postoperative course was satisfactory, with lessening of the jaundice, though she had a mild pulmonary infection with Gram-negative organisms which responded to antibiotic therapy. This was followed by the development of oral candidiasis, which resisted treatment with nystatin. Serial immunofluorescent tests (Dr. Deborah Doniach) showed a gradual decrease of the serum titre of the mitochondrial antibody characteristic of primary biliary cirrhosis from 1 in 1,600 to 1 in 100 over five weeks. There was also a decrease in serum antinuclear factor from a preoperative titre of 1 in 80 to less than 1 in 10 . During the third week she developed steroid-induced diabetes mellitus, but was well and around the ward. Then, following an outbreak of influenza in the ward, she developed progressive pulmonary infection, initially with Staphylococcus aureus and later with Gram-negative organisms and C. albicans, which became resistant to antibiotic therapy, and died in the seventh week after transplantation.

At necropsy there was extensive candidiasis of the pharnx, larynx, and lungs, the last showing diffuse bronchopneumonia with areas of consolidation, some with central cavitation. Cytomegalovirus was identifiable in the lung sections. Four small fungal abscesses were found in the cerebral hemispheres.

\section{Case 12}

A 56-year-old man had been jaundiced in Burma in 1943. In 1963 a portacaval anastomosis was performed after a haematemesis. Subsequently he developed chronic portal systemic encephalopathy and was admitted on a number of occasions with gross tremor, flap, and confusion, which responded initially to protein restriction and neomycin. In January 1968, after further deterioration, a colonic exclusion and caecorectal anastomosis was performed, with some improvement. Later that year he was readmitted and treated with lactulose. The E.E.G. showed a grossly abnormal record.

Transplantation was performed on 27 March 1969. The liver when sectioned showed an inactive mixed micronodular and macronodular cirrhosis with numerous nodules of moderately well differentiated hepatocellular carcinoma, which in many areas showed a transition to the cells of the regeneration nodules.

Apart from an early postoperative chest infection he made an uninterrupted recovery. His mental state improved dramatically. Hepatic flap and fetor could no longer be elicited, and for the first time for five years he was able to have a normal protein intake. The E.E.G. showed much improvement, and by the second week normal alpha components were present, the dominant frequency being 10 cycles/second compared with an average of 2 cycles/second during the preceding six months. He remains well in the fourth month after transplantation.

TABLE I.-Clinical Findings Before Orthotopic Transplantation in 8 Adult Patients Together with Subsequent Course, also Similar Data for Case 11, in Whom Heterotopic Transplantation was Performed

\begin{tabular}{|c|c|c|c|c|c|c|c|}
\hline $\begin{array}{l}\text { Case } \\
\text { No. }\end{array}$ & Sex & Age & Diagnosis & $\begin{array}{l}\text { Clinical } \\
\text { Features }\end{array}$ & $\begin{array}{l}\text { Weight of } \\
\text { Removed } \\
\text { Liver } \\
\text { (g.) }\end{array}$ & $\begin{array}{c}\text { Bile* } \\
\text { Drainage }\end{array}$ & $\begin{array}{l}\text { Subsequent } \\
\text { Course }\end{array}$ \\
\hline $\begin{array}{r}11 \\
3 \\
5\end{array}$ & $\begin{array}{l}\mathrm{M} \\
\mathrm{F} \\
\mathrm{M}\end{array}$ & $\begin{array}{r}2 \\
46 \\
46\end{array}$ & $\begin{array}{l}\text { Biliary atresia } \\
\text { Ca. hepatic duct } \\
\text { Ca. hepatic duct }\end{array}$ & $\begin{array}{l}\text { Bleeding varices } \\
\text { Previous prednisone, } \\
\text { chlorambucil } \\
\text { Previous insertion of poly- } \\
\text { ethylene tube }\end{array}$ & $\begin{array}{c}- \\
2,283 \\
2,410\end{array}$ & $\begin{array}{l}\text { GB to jejunum } \\
\text { GB to } C B D \\
\text { GB to jejunum }\end{array}$ & $\begin{array}{l}\text { Renal failure, then improved, with bile pigments } \\
\text { in stool. Death from pneumonia in 3rd week } \\
\text { Home 36th day, then GB necrosis, sepsis, and } \\
\text { death after } 11 \text { weeks } \\
\text { Recurrent melaena; GB necrosis and sepsis, } \\
\text { death in 4th week }\end{array}$ \\
\hline $\begin{array}{r}4 \\
9 \\
10 \\
\end{array}$ & $\begin{array}{r}\mathrm{M} \\
\mathrm{M} \\
\mathrm{F}\end{array}$ & $\begin{array}{l}40 \\
57 \\
44 \\
\end{array}$ & $\begin{array}{l}\text { Primary hepatoma } \\
\text { Primary cholangio- } \\
\text { carcinoma } \\
\text { Primary hepatoma }\end{array}$ & $\begin{array}{l}\text { Gross hepatic enlargement } \\
\text { Parathyroid hormone pro- } \\
\text { ducing tumour } \\
\text { Gross hepatic enlargement }\end{array}$ & $\begin{array}{l}4,770 \\
2,330 \\
4,000 \\
\end{array}$ & $\begin{array}{l}\mathrm{CBD} \text { to } \mathrm{CBD} \\
\mathrm{CBD} \text { to } \mathrm{CBD} \\
\mathrm{GB} \text { to } \mathrm{CBD}\end{array}$ & $\begin{array}{l}\text { Home 17th day, then chronic jaundice and } \\
\text { death from meningitis in 19th week } \\
\text { Home 48th day. Well apart from biliary fistula, } \\
\text { then pneumonia and death in 10th week } \\
\text { Home 24th day, and doing well in 5th month }\end{array}$ \\
\hline $\begin{array}{r}7 \\
8 \\
12\end{array}$ & $\begin{array}{l}\mathrm{F} \\
\mathrm{M} \\
\mathrm{M}\end{array}$ & $\begin{array}{l}57 \\
17 \\
56\end{array}$ & $\begin{array}{l}\text { Primary biliary } \\
\text { cirrhosis } \\
\text { Subacute hepatic } \\
\text { necrosis } \\
\text { Cryptogenic cirrhosis } \\
\text { and hepatoma }\end{array}$ & $\begin{array}{l}\text { Jaundice, ascites, osteo- } \\
\text { porosis } \\
\text { Coma, bleeding diathesis } \\
\text { Chronic encephalopathy, } \\
\text { portacaval shunt, caeco- } \\
\text { rectal anastomosis }\end{array}$ & $\begin{array}{l}1,750 \\
1,110 \\
1,685\end{array}$ & $\begin{array}{l}\text { CBD to } \mathrm{CBD} \\
\mathrm{CBD} \text { to } \mathrm{CBD} \\
\mathrm{GB} \text { to } \mathrm{CBD}\end{array}$ & $\begin{array}{l}\text { Well, then death from pneumonia in } 7 \text { th week } \\
\text { Died from acute rejection } 6 \text { th day (no immuno- } \\
\text { suppression) } \\
\text { Home } 22 \text { nd day and doing well in } 4 \text { th month }\end{array}$ \\
\hline
\end{tabular}




\section{Liver Function, Histology, and Immunosuppressive Therapy}

During the first 10 postoperative days prednisone was given in a dose of $60 \mathrm{mg}$. daily and azathioprine starting with $50 \mathrm{mg}$. and then increasing to 75-125 mg. daily. The doses subsequently varied according to the patient's clinical state. Cases $4,5,7$, and 9 also received antilymphocyte globulin (kindly supplied by Professor W. Brendal) for 14 to 21 days. This was given in a dose of 10-20 ml. daily over two hours as an intravenous infusion diluted with saline.

\section{Day 1}

Ischaemic damage appeared to be mild as judged by biopsy of the donor liver at the end of the operation and by liver function tests during the first 24-hour period (Table II). In all cases there was a rise in serum aspartate aminotransferase (S.G.O.T.) over the initial preoperative level, but in only one did it exceed 1,000 i.u./100 ml. In two of the three patients with primary hepatomas and initially normal liver function the serum bilirubin rose during the first postoperative day, but most of the rise was in unconjugated bilirubin, suggesting a haemolytic origin from transfused blood. Perhaps the best indication of the very satisfactory liver function was the fall in serum bilirubin observed in those with initially raised levels. In. Cases 3 and 5, with hepatic duct carcinoma and complete biliary obstruction, the levels dropped from 42.0 to 24.0 and from. 17.8 to $8.2 \mathrm{mg} . / 100 \mathrm{ml}$., respectively. This was accompanied. by an even more rapid fall in the serum alkaline phosphatase, the respective levels dropping from 159 to 24 and from 69 to 14 K.A. units $/ 100 \mathrm{ml}$. respectively in the first 24 hours.

During the second, third, and fourth days liver function. continued to be satisfactory. The serum bilirubin fell further and in most cases the serum alkaline phosphatase was within: the normal range and the serum transaminase was normal or only slightly raised.

\section{Day 5 to 28}

Definite changes in the liver function tests were observed in most of the patients at this stage. They occurred earliest in. Case 8, who was not given immunosuppressive therapy. His: serum bilirubin which fell postoperatively started to increase on. the fourth day (Fig. 3). The serum transaminase level rose later, with a dramatic rise to 2,000 i.u. $/ 100 \mathrm{ml}$. on the morning of the: sixth day, when his condition rapidly deteriorated, death. occurring later that day. Necropsy showed the vascular anastomoses to be patent and the liver to be enlarged $(1,950 \mathrm{~g}$.). Histologically, there was pronounced centrilobular haemorrhage and cell necrosis with cholestasis and reticulin condensation.

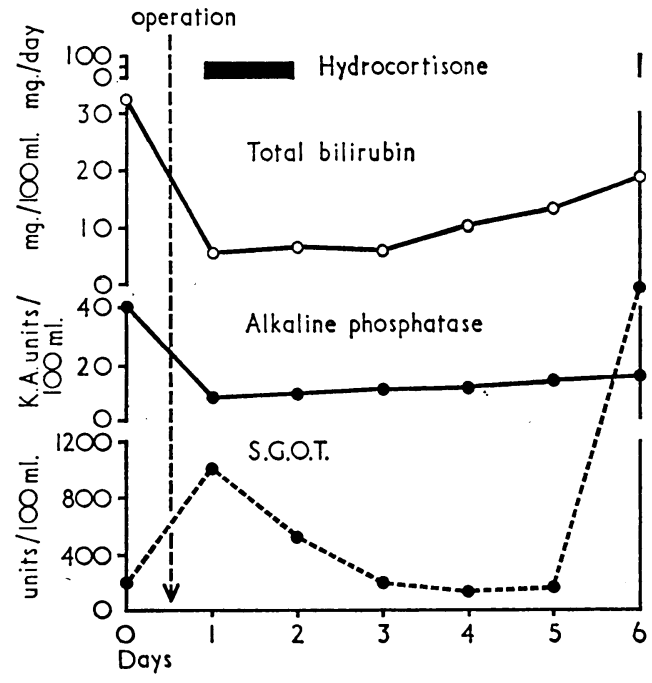

FIG. 3.-Case 8. Liver function tests in the patient who was not given immunosuppressive therapy.
Around the areas of frank necrosis there was fatty change of hepatocytes, sinusoidal dilatation, and numerous eosinophil bodies. Portal tracts were oedematous and contained a dense infiltrate of neutrophil polymorphs, eosinophils, histiocytes, and large lymphoid cells with pyronin-positive cytoplasm ; the lastnamed cells were also scattered throughout the liver parenchyma, especially near necrotic liver cells (Fig. 4).
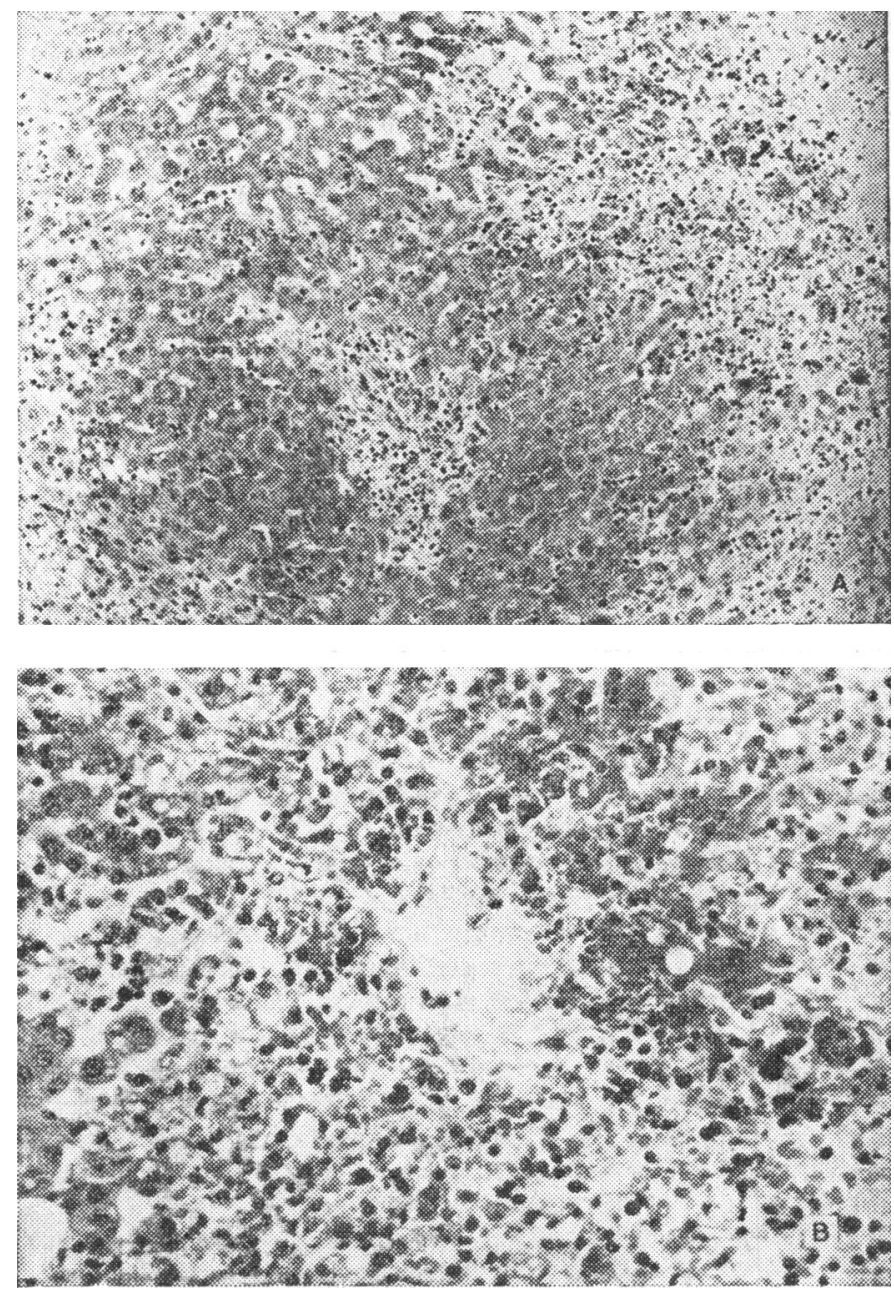

FIG. 4.-Case 8. A, Liver at necropsy, showing massive centrilobular necrosis (left of picture) and infiltrate of parenchyma and portal tract (in centre) by lymphoid cells. (H. and E. $\times 73$.) B, Higher-power view of centrilobular area. (H. and E. $\times 213$.)

Delayed and less-striking changes were observed in five of the seven adult patients (Cases 4, 5, 7, 9, and 10) who were given immunosuppressive therapy. In Case 9, liver function tests on the fifth, sixth, and seventh days were virtually normal (Fig. 5). On the eighth day the serum bilirubin rose to $2 \cdot 2$ mg. $/ 100 \mathrm{ml}$. and there was also a slight rise in serum transaminase. Over the next week the serum bilirubin continued to rise, with an accompanying moderate increase in serum transaminase and alkaline phosphatase levels. The possibility of a toxic reaction to azathioprine was considered, and this was stopped on the 10th day; but there was no improvement, and antilymphocyte globulin, which had been discontinued after the first week owing to lack of supplies, was restarted. On the fourth day the dose of prednisone was increased to $200 \mathrm{mg}$. daily. Subsequently there was a rapid fall in serum bilirubin and transaminase and by the beginning of the fourth week liver function tests were much improved.

In this patient antilymphocyte globulin had been stopped before the deterioration in liver function, but in Cases 5 and 7 similar rises in serum bilirubin and transaminase were observed at this time, though antilymphocyte globulin continued to be given daily. The clinical course in Case 4 at this time was 
previously described in detail (Calne et al., 1968), and in that patient, as in those described here, it appeared to be the increased dose of prednisone which led to control of the jaundice.

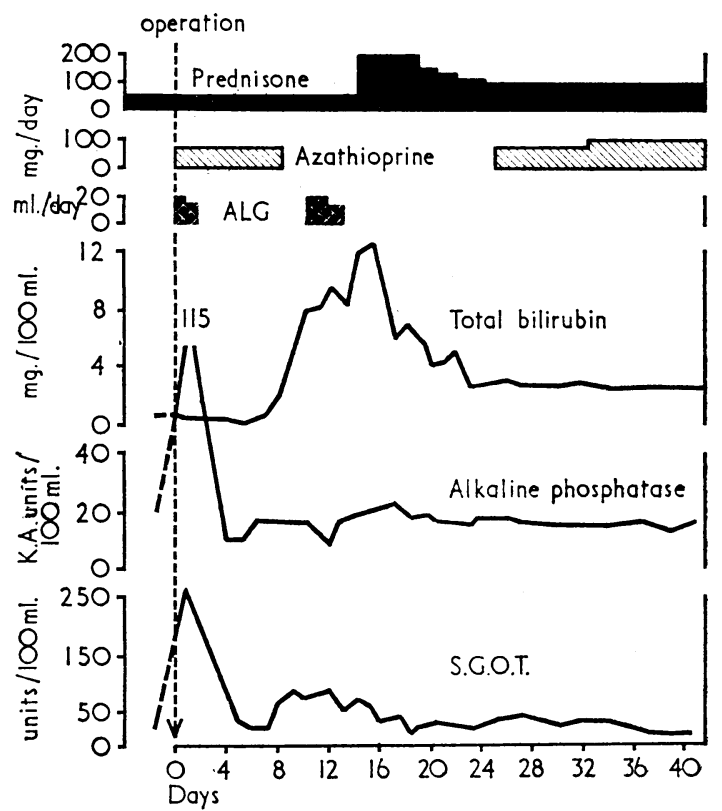

FIG. 5.-Case 9. Liver function tests and immunosuppressive therapy after transplantation, showing characteristic early episode of jaundice.

In Case 10 antilymphocyte globulin was not given, the patient being treated with azathioprine and prednisone. The serum bilirubin, following the postoperative peak, dropped to $1.2 \mathrm{mg}$. $100 \mathrm{ml}$. on the fourth day, but on the seventh day there was a definite rise which was accompanied by an increase in serum alkaline phosphatase and transaminase (Fig. 6). The dose of prednisone was increased immediately, and the serum bilirubin, which reached a peak of $5.8 \mathrm{mg}$. $/ 100 \mathrm{ml}$. on the 10 th day, subsequently fell and by the beginning of the four week was less than $2 \mathrm{mg} . / 100 \mathrm{ml}$. In this patient, in contrast to Case 9, there was a greater rise in alkaline phosphatase, to levels above 30 K.A.u. $/ 100 \mathrm{ml}$.

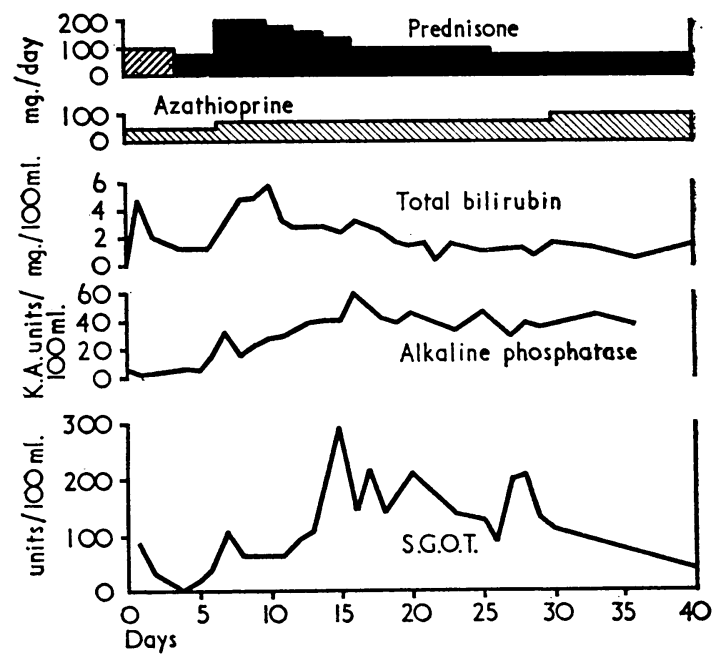

Fig. 6.-Case 10. Liver function tests and immunosuppressive therapy. Note that azathioprine was continued throughout and no antilymphocyte globulin was given.

A high serum alkaline phosphatase was also observed in the early rejection episodes of Cases 4 and 7 . In both these patients, in whom $\mathrm{T}$-tubes were in position, cholangiograms showed no evidence of extrahepatic obstruction. Both patients had been treated with antilymphocyte globulin, and there was no apparent correlation between the type of immunosuppression given and the height of serum alkaline phosphatase, transaminase, or bilirubin level.

Two patients (Cases 3 and 12) showed no rise in serum bilirubin during this period. In Case 3 there was a definite peak of serum transaminase during the second week, though the serum bilirubin, which had fallen from 42 to $5 \mathrm{mg}$. by Day 4 , showed no significant change. In Case 12 the serum bilirubin remained within normal limits, though there was some rise in serum transaminase to $100-200$ i.u. $/ 100 \mathrm{ml}$.

Liver Histology.-Percutaneous biopsies were performed in Cases 4, 7, and 9 during the early period of jaundice. The appearances were similar in all, with centrilobular cholestasis, spotty necrosis of hepatocytes manifest by the presence of acidophil bodies, and a pleomorphic cellular infiltrate of both portal tracts and sinusoids (Fig. 7). Large cells of the lymphoid series with pyroninophilic cytoplasm and others with the histological appearance of plasma cells comprised the majority of the infiltrate. In one biopsy (Case 4) there was slight centrilobular reticulin condensation and haemorrhage but to a much lesser degree than was seen in the patient (Case 8) who died of acute rejection of his liver. Case 7 showed neutrophil polymorphs in the portal infiltrate, suggesting a superimposed ascending cholangitis.

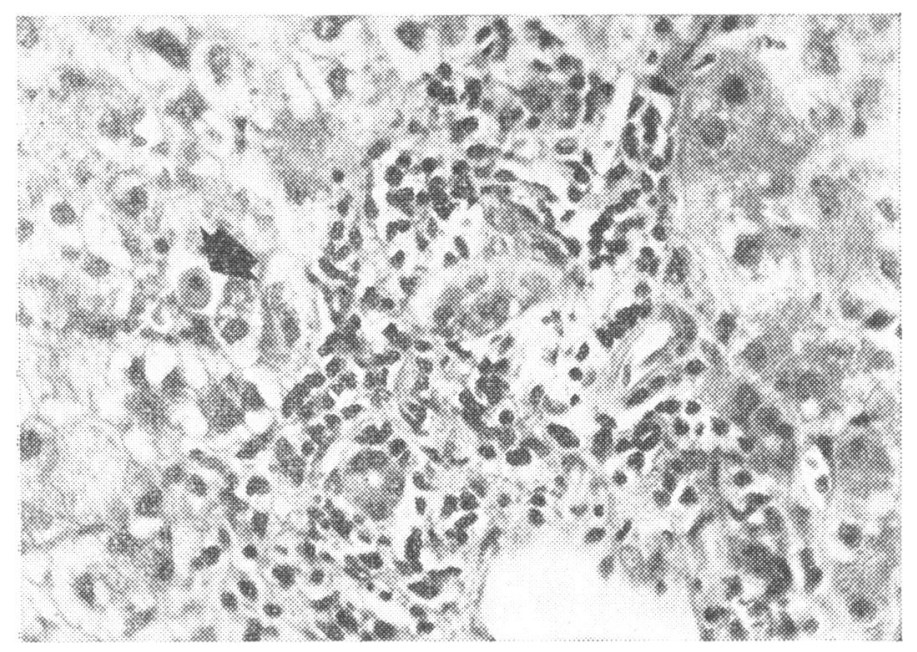

FIG. 7.- Case 9. Liver biopsy taken on 11th day after transplantation, showing portal tract with infiltrate of lymphoid cells and a necrotic hepatocyte with pyknotic nucleus near by (arrowed). (H. and E. $\times 335$.)

\section{Weeks 5 to 8}

During this second month, after the earlier episode of jaundice had been controlled, the dose of prednisone was reduced to $40-$ $60 \mathrm{mg}$. daily and azathioprine continued in a dose of 75-125 mg. daily.

Liver function tests in the six patients alive in this period (including Case 12, who was alive and well in the fourteenth week at time of publication) were satisfactory, with serum bilirubin levels of $0.5-4 \mathrm{mg} . / 100 \mathrm{ml}$. The serum transaminase and alkaline phosphatase were usually slightly raised, with levels of 50-100 i.u./100 ml. and $15-20$ K.A.u. $/ 100 \mathrm{ml}$. respectively.

In Case 7 the serum bilirubin had dropped to $4 \mathrm{mg} . / 100 \mathrm{ml}$. just before her death from pneumonia in the seventh week. Histological examination of the liver showed the architecture to be essentially normal with only slight periportal and minimal septum formation. There was extensive centrilobular reticulin condensation, with collagenous thickening of the walls of the central veins. Around the central veins there was some cell necrosis and haemorrhage, with pronounced cholestasis and many macrophages containing haemosiderin and lipofuscin. Portal tracts contained a slight infiltrate of lymphocytes and polymorphs, but no pyronin-positive cells were seen either here or within the hepatic parenchyma. Only one small focus of foam cells one cell thick on the intima of a single branch of the hepatic artery was found. 


\section{Week 9 Onwards}

In three of the four patients with follow-up periods of more than two months liver function remained satisfactory.

Case 9 , at the time when he was readmitted with an acute pneumonia from which he died, had a serum bilirubin level of $1 \mathrm{mg} . / 100 \mathrm{ml}$., aspartate aminotransferase of 15 i.u. $/ 100 \mathrm{ml}$., and alkaline phosphatase of 15 K.A.u. $/ 100 \mathrm{ml}$. Histological changes in the liver at necropsy were of moderate cholestasis and slight haemorrhage around the central veins. The occasional bile duct contained inspissated bile. There was no portal fibrosis, and, in contrast to the earlier biopsy, no cellular infiltrate in the portal tract. Tumour of similar appearances to that removed was identified in lymph nodes around the coeliac axis.

Case 3 died in the 11 th week from hepatic lobar infarction and sepsis. When the liver was examined at necropsy (Calne et al., 1968) there was no histological evidence of rejection. Case 10 remained well, with virtually normal liver function tests. The serum bilirubin was $0.6 \mathrm{mg} . / 100 \mathrm{ml}$., aspartate aminotransferase 48 i.u. $/ 100 \mathrm{ml}$., and alkaline phosphatase 23 K.A.u./ $100 \mathrm{ml}$. at the time of publication. She was then receiving prednisone $40 \mathrm{mg}$. and azathioprine $125 \mathrm{mg}$. daily.

Case 4 was the one exception. He was well during the second month, but from the ninth week onwards showed a progressive rise of serum bilirubin (Fig. 8) to levels of $30-40 \mathrm{mg} . / 100 \mathrm{ml}$. during the last month of his life. The serum transaminase fluctuated around $200 \mathrm{i} . \mathrm{u} . / 100 \mathrm{ml}$. and there was a considerable increase in alkaline phosphatase (up to 170 K.A.u. $/ 100$ ml.). At no time, however, did he complain of itching. Cytomegalovirus was isolated from the urine, and the serum antibody titre rose from less than 8 to 1,024 . After idoxuridine therapy the titre fell to 512 and virus disappeared from the urine, but there was no improvement in the liver function tests. At necropsy (four and a half months after transplantation) the liver weighed $1,580 \mathrm{~g}$. and the vascular and bile-duct anastomoses were well healed. Histology showed appreciable fibrosis, both periportal and around the central veins, with early septum formation but no nodule formation. Dense centrilobular cholestasis was present and both haemosiderin and lipofuscin were seen in Kupffer cells around central veins. There was no cellular infiltrate. Branches of the hepatic artery had macroscopically thickened walls ; microscopically foamy macrophages contain-

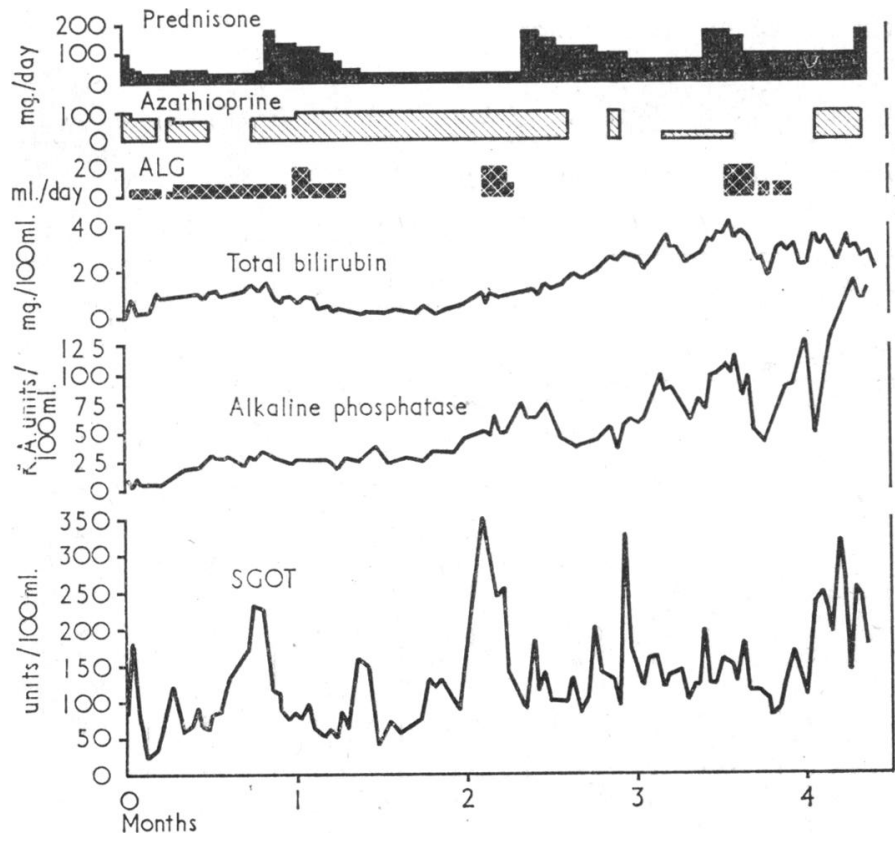

Fig. 8.-Case 4. Liver function tests over four and a half months, illustrnting development of relentless cholestatic jaundice. Note smal scale in serum bilirubin levels. ing lipid were present internal to the internal elastic lamina with cellular fibrous tissue just beneath the intima (Fig. 9).
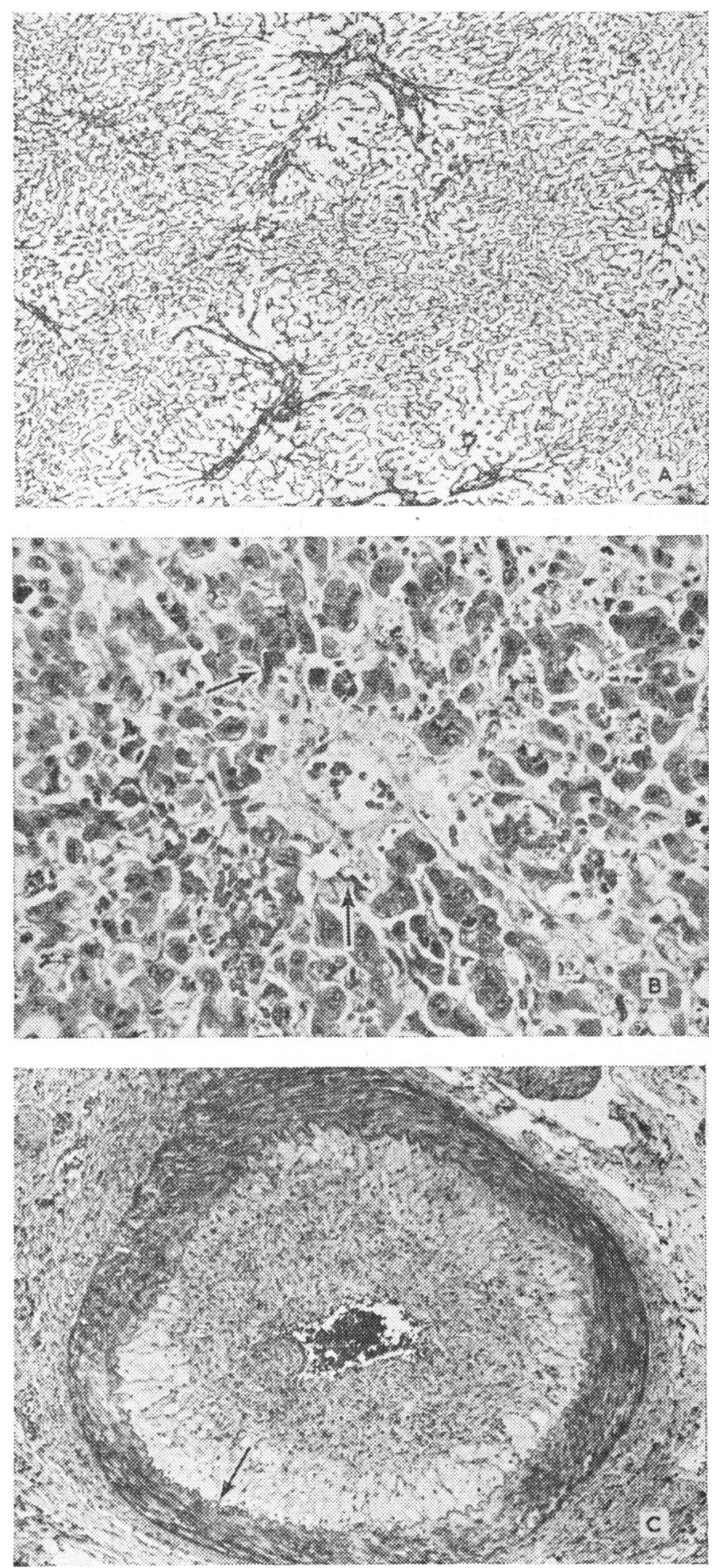

FIG. 9.-Case 4. Histological findings in necropsy material. A, liver tained for reticulin framework showing centrilobular condensation with periportal and septal fibrosis. (Gordon and Sweet. $\times 43$.) B, Centrilobular area showing thickened wall of central vein (centre) and pronounced cholestasis (arrowed). (H. and E. $\times 213$.) C, Medium-sized hepatic artery showing foamy macrophages and cellular fibrous tissue internal to the internal elastic lamina (arrowed). (H. and E. $\times 60$.)

\section{Tissue Typing}

All donor recipient pairs were of the same ABO blood group with three exceptions. In cases 3 and 7 the donor was group $\mathrm{O}$ and the recipient group $\mathrm{A}$. In Case 12 the donor was group $A$ and the recipient $A_{2}$. 
Tissue typing was performed by means of a microcytotoxic test (Joysey, 1969) using sera which included the following specificities-HLA1, HLA2, HLA5, HLA7, " 4a," “4b." In no case was there identity between the donor and recipient, though Case 7 had no major incompatibilities. No relation was observed between the tissue match and the occurrence of early jaundice (Table II). Rejection was the main cause of death in only two cases in the series. Case 8 had two major and two minor incompatibilities and succumbed to acute rejection on day six, but had no immunosuppression. Case 4 had a poor match with four major and one minor incompatibilities, and after progressing well for eight weeks developed the relentless cholestatic jaundice of chronic rejection.

Nevertheless, if the antigenic incompatibilities between donor and recipient have an effect in liver transplantation similar to that found in kidney transplantation, then it is to be expected that the full effect of antigenic disparity between donor and recipient will not be manifest in follow-up periods of only a few months' duration.

\section{Discussion}

Four patients in the Denver series were alive at 14 , 13, 11, and 10 months after orthotopic transplantation (dates to 1 May. Starzl, 1969), so that it is ethical to offer this form of therapy to patients if their prognosis is otherwise less than six months. This, rather than the type of disease, has been the main criterion adopted in the selection of patients in the present series. It can certainly be applied to patients with a primary hepatoma, for most are dead within six months (Lawrence et al., 1966). At least one-third have metastases by the time of diagnosis, and the possibility of small undetectable metastases in the others is a very real one. Of 11 patients with hepatoma in Starzl's series seven died within the first two postoperative months from technical complications and in six of these no tumour was found at necropsy, but of the four survivors all developed a recurrence of the malignancy (Starzl et al., 1969 ; Starzl, 1969). Metastases are rarer with carcinoma of the hepatic duct, the other tumour treated in the present series. These tumours are slowly growing and insertion of a tube through the growth can lead to prolonged relief of the obstructive jaundice (Klatskin, 1965). This may make subsequent transplantation more difficult, for local infection may develop in the porta hepatis, and this undoubtedly contributed to the death of one of our patients.

Each condition, however, has particular problems. The bleeding diathesis of hepatic failure is well known, though the successful transplantation in Case 8 , who had gross deficiency of all clotting factors, shows that the problem can be overcome with correct replacement therapy and with frequent laboratory monitoring (Flute et al., 1969). The presence of portal hypertension makes the bleeding worse, and a previous portacaval anastomosis, as in one of our patients, is undoubtedly an asset rather than a contraindication. The cirrhotic patient is known to have a poor resistance to infection and there is also the problem of hepatoma development. The incidence of the latter is increasing and a hepatoma should always be suspected when the clinical state or liver function tests deteriorate.

Hepatic coma by itself is not a contraindication. It was encouraging to see Case 8 awaking from deep hepatic coma and also how quickly the mental state of Case 12 improved, with a corresponding striking improvement in the E.E.G. The highvoltage slow and sharp complexes seen in the E.E.G. from Case 8 have in our experience always been associated previously with a fatal outcome, and certain of the changes in the recordings from Case 12 had been thought to indicate irreversible brain damage.

The treatment of cirrhosis by transplantation is likely to produce new knowledge about the pathogenesis of the liver damage. In our patient with primary biliary cirrhosis there was a striking fall in titre of the serum mitochondrial antibodies after transplantation. Though the exact relation between this antibody, which is so characteristic of primary biliary cirrhosis, and the liver damage is uncertain, this finding would suggest that the antibody follows rather than precedes its development. A similar decrease in mitochondrial antibody has not been seen after treatment with prednisone or azathioprine, which were used for immunosuppression (Doniach, personal communication).

Technical problems, particularly thrombosis of the hepatic artery, which were related to congenital abnormalities of the vessels of either donor or recipient caused death in the early postoperative period in about a third of the last series of 18 transplants carried out by Starzl since July 1967. Most of these patients, however, were infants or children with small vessels. The most frequent technical problem encountered in the present series has been in relation to bile drainage. The failure of a choledocho-dochostomy to heal may be due to interference with the delicate blood supply of the ducts during operation. The T-tube can also act as a focus of infection, and the procedure used recently of a cholecyst-dochostomy, with preservation of the sphincter of Oddi to prevent ascending cholangitis, has so far proved most satisfactory.

TABLE II.-Data Relating to Donor, Duration of Warm and Total Ischaemia, Tissue Typing, and Liver Function Before (B) and on 1 st Day $(A)$ After Transplantation. Ischaemia Times are from Cessation of Donor Heart Beat to Beginning of Cold Perfusion of Donor Liver (warm) and to Completion of Portal Vein Anastomosis in Recipient (total)

\begin{tabular}{|c|c|c|c|c|c|c|c|c|c|c|c|c|c|}
\hline \multirow{3}{*}{$\begin{array}{l}\text { Case } \\
\text { No. }\end{array}$} & \multicolumn{5}{|c|}{ Donor } & & & \multicolumn{6}{|c|}{ Recipient's Liver Function } \\
\hline & \multirow[t]{2}{*}{$\underset{\text { (years) }}{\text { Age }}$} & \multirow[t]{2}{*}{ Disease } & \multirow[t]{2}{*}{$\begin{array}{l}\text { Ventilator } \\
\text { Time } \\
\text { (hours) }\end{array}$} & \multicolumn{2}{|c|}{$\begin{array}{l}\text { Ischaemia } \\
\text { Time } \\
\text { (minutes) }\end{array}$} & \multicolumn{2}{|c|}{$\begin{array}{l}\text { Tissue Typing } \\
\text { Incompatibilities }\end{array}$} & \multicolumn{2}{|c|}{$\begin{array}{c}\text { Total } \\
\text { Bilirubin } \\
\text { (mg./100 ml.) }\end{array}$} & \multicolumn{2}{|c|}{$\begin{array}{c}\text { Aspartate } \\
\text { Transaminase } \\
\text { (i.u./100 ml.) }\end{array}$} & \multicolumn{2}{|c|}{$\begin{array}{c}\text { Alkaline } \\
\text { Phosphatase } \\
\text { (K.A.u./100 ml.) }\end{array}$} \\
\hline & & & & Warm & Total & Major & Minor & B & A & B & A & B & A \\
\hline 3 & 5 & Encephalitis & 113 & 15 & 141 & $\begin{array}{l}\text { HLA } 1 \\
\text { HLA } 5\end{array}$ & HLA 2 & $42 \cdot 0$ & $24 \cdot 0$ & 83 & 176 & 159 & 24 \\
\hline 4 & 13 & Head injury & 28 & 13 & 119 & $\begin{array}{l}\text { HLA } 1 \\
4 \text { b } \\
\text { HLA } 7\end{array}$ & HLA 5 & 0.5 & $7 \cdot 4$ & 24 & 181 & 13 & 6 \\
\hline 5 & 64 & Head injury & 16 & 4 & 94 & ${ }_{4 \mathrm{~b}}^{\mathrm{HLA}} 1$ & $\begin{array}{l}\text { HLA } 2 \\
4 \mathrm{a}\end{array}$ & $17 \cdot 8$ & $8 \cdot 2$ & 44 & 200 & 69 & 14 \\
\hline $\begin{array}{l}7 \\
8\end{array}$ & $\begin{array}{l}43 \\
43\end{array}$ & $\begin{array}{l}\text { Cerebral haemorrhage } \\
\text { Subarachnoid } \\
\text { haemorrhage }\end{array}$ & $\overline{22}$ & $\begin{array}{r}13 \\
5\end{array}$ & $\begin{array}{l}123 \\
124\end{array}$ & $\begin{array}{l}\text { None } \\
4 \mathrm{~b} \\
\text { HLA } 7\end{array}$ & $\begin{array}{l}\text { HLA } 1 \\
4 a\end{array}$ & $\begin{array}{l}12 \cdot 1 \\
20 \cdot 5\end{array}$ & $\begin{array}{r}11 \cdot 7 \\
5 \cdot 2\end{array}$ & $\begin{array}{l}40 \\
56\end{array}$ & $\begin{array}{r}1,170 \\
990\end{array}$ & $\begin{array}{l}50 \\
34\end{array}$ & $\begin{array}{r}25 \\
5\end{array}$ \\
\hline 9 & 53 & Cerebral haemorrhage & 8 & 8 & 94 & $4 \mathrm{~b}$ & $\begin{array}{l}\text { HLA } 1 \\
\text { HLA } 2 \\
4 a\end{array}$ & $0 \cdot 8$ & $0 \cdot 8$ & 69 & 262 & 40 & 10 \\
\hline 10 & 4 & Head injury & 48 & 5 & 108 & $4 a$ & HLA 2 & 0.5 & $4 \cdot 2$ & 5 & 90 & 8 & 3 \\
\hline 11 & $2 / 12$ & $\begin{array}{l}\text { Microcephalus; } \\
\text { pneumonia }\end{array}$ & 0 & 18 & 208 & HLA 5 & $\begin{array}{l}\text { HLA } 7 \\
\text { HLA } 2\end{array}$ & $16 \cdot 5$ & $27 \cdot 0$ & 94 & 422 & 26 & 21 \\
\hline 12 & 36 & Head injury & 26 & 5 & 138 & HLA 7 & $\begin{array}{l}\text { HLA } 1 \\
\text { HLA } 5\end{array}$ & $2 \cdot 3$ & $4 \cdot 2$ & 85 & 230 & 15 & 6 \\
\hline
\end{tabular}


The early episodes of jaundice due to rejection observed in the present patients followed a characteristic pattern, with a similar timing, changes in liver function and histology, and response to an increase in prednisone dose. The onset was earliest in the patient who was not treated by immunosuppression, and it is known that the treatment of hepatic rejection in dogs with azathioprine delays rather than alters the characteristics of the rejection episode (Starzl et al., 1967). The histological features observed of early portal tract infiltration and centrilobular cholestasis, with a later loss of centrilobular cells followed by reticulin condensation, are similar to those found by Porter in the dog after hepatic transplantation and in the human cases at Denver (Starzl et al., 1967, 1969).

On the basis of electron microscopy studies in the dog, Porter suggested that during the first few days after transplantation sensitized lymphocytes of the host infiltrated the portal tracts and then passed from the sinusoids into the spaces of Disse, damaging both sinusoidal wall and surrounding hepatic cells. The centrilobular reticulin condensation may resolve or progress to link up adjoining areas with the development of a true cirrhosis. This happened in three of Starzl's patients who survived 133, 61, and 382 days. The first patient had a hepatoma and the other two biliary atresia, so that the original disease cannot be implicated. In our patient who died at four and a half months there was pronounced cholestasis and septal fibrosis but no cirrhosis.

One feature of interest in the latter patient was the obliteration of the small hepatic arteries by fibrin deposition and intimal proliferation. Similar lesions have been found in kidney transplants undergoing chronic rejection (Ponter, 1967). Their development is almost certainly related to the low-grade but continued intravascular coagulation found by Flute et al. (1969) in some of the present patients.

In Starzl's series there was no correlation between severity of rejection or the long-term survival and the degree of compatibility as shown by leucocyte typing. This may be because of so many complicating technical factors. In the present series there was no complete correlation between tissue typing and the early rejection episodes. Nevertheless, the one patient with the relentless cholestatic jaundice of chronic rejection had a poor tissue match. With a larger number of potential recipients tissue-typed prospectively it should be possible to prevent the occurrence of multiple incompatibilities.

Antilymphocyte globulin did not prevent the early rejection episodes, and, indeed, we could find little evidence of a beneficial effeot from intravenous antilymphocyte globulin in the present patients. Starzl, in contrast, bases his immunosuppression during the first three months on a daily intramuscular injection of antilymphocyte globulin, giving as well prednisone and a small dose $(12.5 \mathrm{mg}$.) of azathioprine. He finds that dependence on antilymphocyte globulin occurs, and when it is withdrawn jaundice often follows shortly afterwards. Though azathioprine is a known hepatotoxic drug and produces jaundice regularly in dogs after hepatic transplantation (Starzl et al., 1967), we have not found this in the present patients. Antilymphocyte globulin is likely to be in short supply in this country for some time to come, and at present there is no reliable means for measuring its potency.

Infection was a major cause of death in this series. As in
Starzl's experience, the most important organisms were Gramnegative bacilli and fungi (Fulginiti et al., 1968), and these infections often followed broad-spectrum antibiotic therapy. Recently our policy has been to use short courses of narrowspectrum antibiotics for specific infections and to omit prophylactic therapy. Other factors increasing susceptibility to infection were the presence of insulin-dependent diabetes mellitus in three patients (Cases 4, 7, and 12), profound neutropenia in two (Cases 4 and 5), and the influenzal infection in Case 7. The development of widespread arteriolar occlusion by fibrin thrombi (Flute et al., 1969) may also lead to diminished tissue resistance to infection. We have also noted that intermittent bacteraemia may occur for many weeks after transplantation. The organisms have often been the same as those isolated from the bile, but there has been no evidence of cholangitis or liver infarction and it has not been our policy to give antibiotic therapy.

The exact importance of cytomegalovirus infection which occurred in at least three of our patients (Cases 4,7 , and 9) is uncertain. Definite cases of jaundice, often with features of cholestasis, have been reported with cytomegalovirus infection (Toghill et al., 1967). Histologically, cytomegalovirus hepatitis may be difficult to distinguish from viral or serum hepatitis, which may also be expected to occur in a significant incidence in these patients, either from the blood or from fresh frozen plasma.

Indeed, there are many possible causes of jaundice after transplantation, and the distinction of these from rejection is of considerable importance. However, Eddleston et al., (1969) have shown that the leucocyte-migration test of Bendixen, which gives a quantitative measure of cellular immune response, may be used as a rapid in-vitro test of rejection. The use of this test should also enable more exact titration of the immunosuppressive therapy, and this in turn may reduce the incidence and dangers of infection.

We wish to thank particularly the theatre, nursing, and physiotherapy staff and other colleagues who have contributed so much to the care of these patients. We are indebted to the departments of chemical pathology and bacteriology for their willing help with the loads imposed and grateful to Mrs. M. Allen and Mrs. Angela Birbeck for preparing the drawings.

\section{REFERENCES}

Calne, R. Y., and Williams, R. (1968). British Medical fournal, 4, 535. Calne, R., et al. (1968). British Medical fournal, 4, 541 .

Eddleston, A. L. W. F., Williams, R., and Calne, R. Y. (1965). Nature, 223, 674

Flute, P T., et al. (1969). British Medical fournal, Fulginiti, V. A., et al. (1968). New England fournal of Medicine, 279,
619 .

Joysey, V. (1969). Proceedings of the Symposium on Transplantation Antigens and Tissue Typing, p. 125, edited by M. W. Elves and N. W. Nisbet. Robert Jones and Agnes Hunt Orthopaedic Hospital
Management Committee.

Klatskin, G. (1965). American fournal of Medicıne, 38, 241.

Lawrence, G. H., Grauman, D., Lasersohn, J., and Baker, J. W. (1966). American fournal of Surgery, 112, 200.

Porter, K. A. (1967). fournal of Clinical Pathology, 20, 518.

Starzl, T. E. (1969). British Medical fournal, 2, 306.

Starzl, T. E., Marchioro, T. L., and Porter, K. A. (1966). Advances in Surgery, 2, 370.

Starzl, T. E., et al. (1969). Surgery, Gynaecology, and Obstetrics, 128,

Toghill, P. J., Bailey, M. E., Williams, R., Zeegen, R., and Bown, R. 